\title{
THIS BUSINESS OF DYING
}

I don't care at all who died today. There's not a single reason to list the deaths today. Maybe my father opens the sports page or my mother a mystery novel in New York this afternoon, a place where on another day I could follow death like a woman into the subway, where death is just a headline, where boys light freezing derelicts on fire.

So let's forget who died today, the families, their keepsakes, the clumsy last breaths.

Because this afternoon I know

I've invested my heart in good places, that if this woman drops off to sleep right now I'll still be here exhaling, feeling guilty but lucky, like a man with no connections.

Because everyone left for work today loving their children but cursing their lives.

Some union men, on strike again, lounged in taverns, lost count of their beers

as I've lost count of these hours, this afternoon, the days I've run through, and the women who moved me this far, so far from my death. 